\title{
Identifying the Problems Experienced By Families of Children with Burn Injuries After Discharge and The Causes of These Problems*
}

\author{
Yanıklı Çocukların Ailelerinin Taburculuk Sonrası \\ Yaşadıkları Sorunların ve Nedenlerin Belirlenmesi
}

Nazife Gamze Ozer $\oplus^{\oplus}$

Fatma Vural $\odot$

\begin{abstract}
Objective: Burns alter normal life processes suddenly. It is hard both to accept burns due to accompanying physical and psychological changes and to learn how to live with the generally altered appearance caused by them. The study was conducted to identify the problems experienced by families of children with burn injuries after discharge and the causes of these problems.

Method: The descriptive study data were collected with the help of an introductory form, an information form for the problems experienced by parents and the State Anxiety Inventory. Statistical Package for the Social Sciences 16.0 program was used in data analysis. Study data were expressed as numbers, percentages, means using Student's $t$ test.

Results: The sample included 162 families of children with burns. Of these children, 54.3\% were males, while $70.4 \%$ of them had scalding and $46.3 \%$ had superficial burns. Families had experienced problems with their children concerning bathings (81.5\%), social communication (77.8\%), getting dressed (63.0\%), using medications (61.7\%), doing exercises (54.3\%), feeding (40.7\%) and dressing wounds (34.6\%). Mean state anxiety score was found to be $47.03 \pm 7.48$.

Conclusion: This study found that parents experienced various problems after discharge: Problems with using medication, dressing wounds, bathing, getting dressed, exercise, nutrition and social communication were experienced. It was determined that problems experienced affected the anxiety levels of the families. It is suggested for nurses to provide regular home visits or provide consultancy via telephone in order to identify problems. Identification of the problems expeirenced will also contribute to the preparation of the content discharge training programs.
\end{abstract}

Keywords: Child, burn, nursing, family, home care

öz

Amaç: Yanıklar ani bir şekilde normal yaşam süreçlerini değiş̧irmektedir. Eşlik eden fiziksel ve psikolojik değişikliklerden dolayı yanıkları kabul etmek ve yanıkların neden olduğu genel olarak değiştirilmiş görünümle nasıl yaşayacağını öğrenmek zordur. Bu çalışma taburculuk sonrası yanık yaralanması olan çocukIarın ailelerinin yaşadığı sorunları ve nedenlerini belirlemek amacıyla yapıldı.

Yöntem: Tanımlayıcı çalışma verileri, tanımlayıcı özelliklere ait bilgi formu, ailelerin yaşadığı sorunlara ilişkin bilgi formu ve Durumluk Kaygı Envanteri yardımı ile toplandı. Veri analizinde Sosyal Bilimler İstatistik Paketi 16.0 programı kullanılarak sayı, yüzde, ortalama ve t testi hesaplandı.

Bulgular: Örneklemde 162 yanıklı çocuğun ailesi dahil edildi. Çocukların \%54,3’ü erkek, \%70,4'ü haşlanma ve \%46,3'ü yüzeysel yanıktır. Ailelerin \%81,5'inin banyo, \%77,8'sinin sosyal iletişim, \%63,0'nün giyinme, \%61,7'sinin ilaç kullanma, \%54,3'nün egzersiz yapma, \%40,7'sinin beslenme, \%34,6'sının pansuman

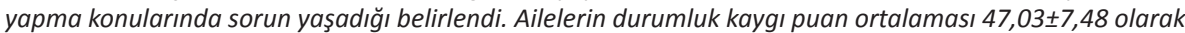
bulundu.

Sonuç: Bu çalışma ailelerin taburcu olduktan sonra çeşitli sorunlar yaşadıklarını ortaya koydu. Bu sorunlar; ilaç kullanma, yaraları giyinme, banyo yapma, giyinme, egzersiz, beslenme ve sosyal iletişim sorunlarıdır. Yaşanan sorunların ailelerin kaygı düzeylerini etkilediği belirlendi. Hemşirelerin ailelerin yaşadıkları sorunları tespit etmek için düzenli ev ziyaretleri yapmaları veya telefonla danışmanlık yapmaları önerilmektedir. Ayrıca, yaşanan sorunların belirlenmesi taburculuk eğitiminde yer alan içeriğin hazırlanmasına katkıda bulunacaktır.

Anahtar kelimeler: Çocuk, yanık, hemşirelik, aile, evde bakım
Received/Geliş: 06.12.2019

Accepted/Kabul: 03.02.2020

Published Online/Online Yayın: 31.08.2020

Nazife Gamze Ozer PhD Student at Dokuz Eylul University, Institute of Health Sciences, Izmir, and Research Assistant at Dokuz Eylül University, Faculty of Nursing, Department of Surgical Nursing İzmir, Turkey gamzeozerozlu@gmail.com ORCID: 0000-0003-1144-2472

F. Vural 0000-0001-6459-2584 Dokuz Eylül University, Faculty of Nursing, Department of Surgical Nursing, izmir, Turkey

*This study was submitted as an oral presentation in two congresses, $20^{\text {th }}$ National Surgery Congress and $15^{\text {th }}$ Surgery Nursing Congress in Antalya, Turkey, on 13-17 May, 2016 and $34^{\text {th }}$ National Pediatric Surgery Congress and $20^{\text {th }}$ National Pediatric Surgery Nursing Congress in the Turkish Republic of Cyprus on 26-30 Oct, 2016. 


\section{INTRODUCTION}

Burn injuries in children are serious affairs that require hospitalization and long- term rehabilitation (1). Children's burn injuries instantly ruin their normal lives ${ }^{(2,3)}$, creating difficult periods due to physical and psychological changes and altering their external appearance ${ }^{(4-7)}$. Therefore, it may take a long time for children to adapt themselves to their normal life after burn injuries ${ }^{(4,7)}$.

Burn management continues at home after discharge, and family members are the primarily responsible for it ${ }^{(8,9)}$. It has been reported that families experience difficulties and anxiety during this period (10-12) since the physical problems they expeirenced alter their daily life, effect family relationships, and the need for parental and family support emerges (13-15). Families may feel alone in caring for the child and need professional support.15 Nurses should also provide support to prevent possible problems $(3,10,16,17)$. No studies have been found in the literature that investigated all these topics (taking medication, dressing wounds, bathing and getting dressed, exercise, nutrition and social communication). The researchers observed that in the burn unit where the study was conducted, the mothers had problems with six areas after discharge, which are the focus of this study.

The results of this study will be instrumental in determining the kind of support for home care that should be provided to children with burn injuries and their parents. The purpose of this study was to identify the problems experienced by families of children with burn injuries after discharge and their causes.

\section{MATERIALS and METHODS}

\section{Study Questions and Methodology}

Since this is a descriptive study, no hypotheses were formed. Research questions were as follows,

1. Does sociodemographic characteristics affect problems after discharge (children's age and gender, maternal and paternal age, profession and education, socioeconomic level, social security status of the family, place of residence)?

2. Do the characteristics of the burn affect problems after discharge (type of burn, total body surface area burned, location, and degree of burn, receiving consultancy)?

3. What are the problems related to burns after discharge (using medication, dressing wounds, bathing, getting dressed, exercise, nutrition and social communication)?

4. Does the type of burn relate to the level of parental anxiety?

\section{Study Populations}

This study was conducted with the families of 162 children under the age of 18 with burn injuries who visited the burn clinic of a university hospital between January and May 2015. The burn clinic serves patients five days a week, extensively on Mondays and Wednesdays from nine to four. Medical dressings for burns are applied on Mondays, Tuesdays, Thursdays and Fridays. Wednesdays are generally spent on burn assessment. The wounds of the children who come to the outpatient clinic are dressed by the polyclinic nurses. Discharge training is provided by the nurses responsible for caring for burn injuries, training nurses and physicians. General post-burn checkups are done in the first week, first and third months and subsequently, every three months. In the first week, the children's wounds are evaluated. In later checkups, the condition of their wounds is evaluated based on external problems. In the first month after burn injuries, more problems are experienced due to the acute stress of mothers and fathers.

\section{Data Collection Forms}

This study used a child and family introductory form developed by researchers based on a review of the literature $(1,2,4,7-10,13,17,18)$ the Data Collection Form for Problems Experienced by Parents After Discharge and the State Anxiety Inventory ${ }^{(19)}$.

The child and family introductory form has two sections. The first section includes sociodemographic characteristics (child's age and gender, maternal and parenteral age, profession and education, socio- 
economic level, social security status of the family, place of residence). The second section includes the characteristics of the burn (type of burn, total body surface area burnt, location, and degree of burn, receiving consultancy).

The Data Collection Form for Problems Experienced by Parents after Discharge includes questions related to the problems experienced by the families of children with burn injuries after discharge. The form has six section: taking medication, dressing wounds, bathing and getting dressed, exercise, nutrition and social communication. These sections were developed by the researchers based on the relevant literature in order to identify the problems experienced by the parents of the children with burn injuries during home care. The researchers developed this form. Because a similar form was not found in the literature. In each section, problem with burn care is responded by Yes/No Six items are provided to identify the causes of the problems experienced by parents.

Before data collection, child and family introductory form and the Data Collection Form for Problems Experienced by Parents after Discharge were reviewed by two physicians who are experts in the field of burns, two clinical nurses and two academic nurses. The forms were revised based on their views and pilot tested with the parents of 10 children with burn injuries to assess their usefulness. After the form was finalized, the data were collected.

The State Anxiety Inventory was used to determine the anxiety levels of the parents of children with burn injuries as a result of problems encountered after discharge. Because this scale is commonly used to measure how families are affected by their concerns. It is one of the most commonly used scales in the world. Implementation is simple and easy to use. It is a Likert-type scale with 20 items. It was developed by Spielberg et al. in 1970 and adapted into Turkish by Le Compte and Öner in 1985. High scores on the scale indicate high anxiety levels ${ }^{(19)}$.

\section{Data Collection}

After obtaining the ethical committee's approval, the study was conducted with the parents of child- ren with burn injuries who came for checkups or medical dressing in the first month after discharge between January and May 2015. Families were informed about the purpose and method of the study. Signed informed consent forms were obtained from the parents of children with burn injuries who came for checkups or medical dressing in the first month of discharge between January and May 2015.

\section{Ethical Approval}

To the end of implementation of the study, a written consent from the university medical faculty hospital was issued (date of endorsement: 22.12.2014; approval code: 69631334-2138-27315); and the relevant permission was issued by the board of ethics of the university noninvasive clinical research evaluation commission (date of endorsement: 22.01.2015; approval code: 2015/02-29).

Before the interview, purpose and application method of the study were explained to the families. Volunteered families were instructed to sign a consent form for the record.

\section{Statistical Analysis}

SPSS (Statistic Package for the Social Sciences) 16.0 was used for data analysis ${ }^{(20,21)}$. The threshold for significance was $0.05^{(20,21)}$. Numbers, percentages and means were used in the data analysis of sociodemographic and burn characteristics. The significance test for the difference between two means was used to compare the problems experienced by the parents of the children with burn injuries and their mean state anxiety scores.

\section{RESULTS}

Sociodemographic characteristics of the children and their families and the features of their burns are shown in Tables 1 and 2. The mean age of the 162 children with burn injuries who participated in the study was found to be $3.4 \pm 3.38$ years. It was found that $70.4 \%$ of their burn types were due to scalding. Burns covering $72.8 \%$ of total body surface area were detected in $1-10 \%$ of all incidents, and $43.8 \%$ of the children with burn injuries had burns on their 
Table 1. Child and family introductory characteristics (n:162).

\begin{tabular}{|c|c|c|c|}
\hline Introductory Characteristics & & Number (n) & $\%$ \\
\hline \multicolumn{4}{|l|}{ Child's Age } \\
\hline $0-3$ years & & 101 & 62.3 \\
\hline $4-6$ years & & 32 & 19.8 \\
\hline $7-12$ years & & 22 & 13.6 \\
\hline $13-18$ years & & 7 & 4.3 \\
\hline \multicolumn{4}{|l|}{ Child's Gender } \\
\hline Female & & 74 & 45.7 \\
\hline Male & & 88 & 54.3 \\
\hline \multicolumn{4}{|l|}{ Mother's Age } \\
\hline 20-29 years & & 59 & 36.4 \\
\hline 30-39 years & & 86 & 53.1 \\
\hline $40-59$ years & & 17 & 10.5 \\
\hline \multicolumn{4}{|l|}{ Father's Age } \\
\hline $20-29$ years & & 25 & 15.4 \\
\hline $30-39$ years & & 96 & 59.3 \\
\hline $40-49$ years & & 35 & 21.6 \\
\hline $50-59$ years & & 6 & 3.7 \\
\hline \multicolumn{4}{|l|}{ Mother's Level of Education } \\
\hline Illiterate & & 7 & 4.3 \\
\hline Primary & & 102 & 63.0 \\
\hline Secondary & & 31 & 19.1 \\
\hline Higher Education & & 22 & 13.6 \\
\hline \multicolumn{4}{|l|}{ Father's Level of Education } \\
\hline Illiterate & & 1 & 0.6 \\
\hline Primary & & 98 & 60.5 \\
\hline Secondary & & 46 & 28.4 \\
\hline Higher Education & & 17 & 10.5 \\
\hline \multicolumn{4}{|l|}{ Mother's Profession } \\
\hline Employee & & 5 & 3.1 \\
\hline Retired & & 1 & 0.6 \\
\hline Housewife & & 138 & 85.2 \\
\hline Other (cosmetician etc.) & & 18 & 11.1 \\
\hline \multicolumn{4}{|l|}{ Father's Profession } \\
\hline Civil Servant & & 6 & 3.7 \\
\hline Employee & & 83 & 51.2 \\
\hline Retired & & 2 & 1.2 \\
\hline Other (hospital worker etc.) & & 71 & 43.8 \\
\hline \multicolumn{4}{|c|}{ Socio-economic Income Level of the Family } \\
\hline İncome=Expenditure & & 120 & 74.1 \\
\hline Income $<$ Expenditure & & 4 & 2.5 \\
\hline Income $>$ Expenditure & & 38 & 23.5 \\
\hline \multicolumn{4}{|l|}{ Place of Residence } \\
\hline Province & & 116 & 71.6 \\
\hline District & & 37 & 22.8 \\
\hline Village & & 9 & 5.6 \\
\hline \multirow[t]{2}{*}{ Total } & & 162 & 100 \\
\hline & $X \pm S S$ & Min & Max \\
\hline Child's Age & $3.40 \pm 3.38$ & 0.091 & 17.00 \\
\hline Mother's Age & $31.53 \pm 5.88$ & 19.004 & 48.00 \\
\hline Father's Age & $35.68 \pm 6.33$ & 25.005 & 59.00 \\
\hline Child's Weight & $15.90 \pm 11.23$ & $\begin{array}{lll}3 & 6.00 \quad 7\end{array}$ & 79.00 \\
\hline Child's Height & $94.07 \pm 23.98$ & $8 \quad 52.001$ & 180.00 \\
\hline
\end{tabular}

upper extremities. In terms of degree, $46.3 \%$ of the children with burn injuries had superficial dermal
Table 2. Burn characteristics ( $\mathrm{n}: 162)$.

\begin{tabular}{|c|c|c|}
\hline Burn Characteristics & Number (n) & $\%$ \\
\hline \multicolumn{3}{|l|}{ Type of Burn } \\
\hline Scalding/hot water & 114 & 70.4 \\
\hline Scalding/hot milk & 25 & 15.4 \\
\hline Contact burns (stove, iron) & 17 & 10.5 \\
\hline Flame/fire & 4 & 2.5 \\
\hline Electrical & 2 & 1.2 \\
\hline \multicolumn{3}{|l|}{ Burned Total Body Surface Area } \\
\hline $1-10 \%$ & 118 & 72.8 \\
\hline $11-20 \%$ & 23 & 14.2 \\
\hline $21-30 \%$ & 10 & 6.2 \\
\hline $31-40 \%$ & 5 & 3.1 \\
\hline $41 \%$ or more & 6 & 3.7 \\
\hline \multicolumn{3}{|l|}{ Degree of Burn } \\
\hline Epidermal burn & 12 & 7.4 \\
\hline Superficial dermal burn & 75 & 46.3 \\
\hline Deep dermal burn & 69 & 42.6 \\
\hline Third degree burns & 6 & 3.7 \\
\hline $\begin{array}{l}\text { Receiving Post Burn Psychological or } \\
\text { Psychiatric Support }\end{array}$ & & \\
\hline No & 91 & 56.2 \\
\hline Yes & 71 & 43.8 \\
\hline \multicolumn{3}{|l|}{ Who Provided Support After Burn (n:71)* } \\
\hline Psychologist & 64 & 91.5 \\
\hline Psychologist or psychiatrist & 7 & 8.5 \\
\hline $\begin{array}{l}\text { Receiving Training or Consultancy After } \\
\text { Discharge }\end{array}$ & & \\
\hline No & 100 & 61.7 \\
\hline Yes & 62 & 38.3 \\
\hline \multicolumn{3}{|l|}{$\begin{array}{l}\text { Who Provided Training or Consultancy After } \\
\text { Discharge }(\mathrm{n}: 62)^{* *}\end{array}$} \\
\hline Nurse & 49 & 80.3 \\
\hline Physician & 8 & 13.0 \\
\hline Nurse-Physician & 5 & 6.7 \\
\hline Total & 162 & 100 \\
\hline
\end{tabular}

*People receiving psychological or pyschiatric support after burn **People receiving discharge training after burn

Table 3. Whether parents experienced problems following discharge.

\begin{tabular}{lcc}
\hline $\begin{array}{l}\text { Whether Parents Experienced Problems } \\
\text { Following Discharge }\end{array}$ & Number $(\mathbf{n})$ & $\%$ \\
\hline Using medication & & \\
Problems & 100 & 61.7 \\
No problems & 62 & 38.3 \\
Dressing wounds & 56 & 34.6 \\
Problems & 106 & 65.4 \\
No problems & & \\
Taking baths & 132 & 81.5 \\
Problems & 30 & 18.5 \\
No problems & & \\
Getting dressed & 102 & 63.0 \\
Problems & 60 & 37.0 \\
No problems & & \\
Doing exercises & 88 & 54.3 \\
Problems & 74 & 45.7 \\
No problems & & \\
Feeding & 66 & 40.7 \\
Problems & 96 & 59.3 \\
No problems & & \\
Social communication & 126 & 77.8 \\
Problems & 36 & 22.2 \\
No problems & 162 & 100 \\
TOTAL & & \\
\hline
\end{tabular}


burns, and $42.6 \%$ had dermal burns involving deeper layers (Tables 1 and 2).

Table 3 presents the findings concerning the parents of children with burn injuries who experienced problems and Table 4 displays the causes of these problems. It was determined that chldren of the parents experienced problems with bathing in $81.5 \%$, social communication in $77.8 \%$, getting dressed in $63.0 \%$, using medication in $61.7 \%$, doing exercises in $54.3 \%$, feeding in $40.7 \%$, and dressing wounds

Table 4. Causes of problems experienced after discharge.

\begin{tabular}{|c|c|c|}
\hline Causes of Problems Experienced After Discharge & Number (n) & $\%$ \\
\hline \multicolumn{3}{|l|}{ Problems regarding using medication ( $\mathrm{n}: 318)$} \\
\hline Not knowing the significance of the medication in improving the burn wounds & 109 & 67.3 \\
\hline Not knowing how to use medication after discharge & 151 & 93.2 \\
\hline The child has allergies about the medication & 4 & 2.5 \\
\hline The child does not want to take medication & 32 & 19.8 \\
\hline The child throws up when he/she is forced to take medication & 15 & 9.3 \\
\hline Other (the family forgets to use medication etc.) & 7 & 4.3 \\
\hline \multicolumn{3}{|l|}{ Problems regarding dressing wounds (n:58) } \\
\hline Not knowing the importance of dressing wounds after discharge & 6 & 3.7 \\
\hline The child feels pain after his wounds are dressed & 19 & 11.7 \\
\hline There is no healthcare organization in close vicinity to the house & 21 & 13.0 \\
\hline The child has distorted body image based on the trauma that has been experienced & 4 & 2.5 \\
\hline Wounds are not dressed believing the burn injury healed & 5 & 3.1 \\
\hline Other (not knowing how to dress the wound in grafting area etc.) & 3 & 1.9 \\
\hline \multicolumn{3}{|l|}{ Problems regarding taking baths ( $\mathrm{n}: 190)$} \\
\hline Not knowing the importance of taking baths after discharge & 7 & 4.3 \\
\hline The child is scared of taking baths & 61 & 37.7 \\
\hline Fearing that the bath will hurt the area injured by burn & 67 & 41.4 \\
\hline Fearing for development of infections in burn area & 32 & 19.8 \\
\hline Believing that taking baths will delay healing of the burn injury & 19 & 11.7 \\
\hline Other (not knowing how to give a bath in dressed areas etc.) & 4 & 2.5 \\
\hline \multicolumn{3}{|l|}{ Problems regarding getting dressed $(n: 140)$} \\
\hline Not knowing the importance of the clothes the child wears after discharge & 2 & 1.2 \\
\hline Fearing that the clothes that the child wears will hurt the burn injury & 43 & 26.5 \\
\hline Financial difficulties to purchase clothing that is appropriate for the burn injury & 16 & 9.9 \\
\hline Inability to find clothing that will protect the burn injury from sun rays & 14 & 8.6 \\
\hline The child feels pain while getting dressed & 59 & 36.4 \\
\hline Other (preferring larger shoes in case of burn injury in feet etc.) & 6 & 3.7 \\
\hline \multicolumn{3}{|l|}{ Problems regarding doing exercises (n:115) } \\
\hline Not knowing the importance of doing exercises after discharge & 30 & 18.5 \\
\hline The child's pain increases during exercise & 28 & 17.3 \\
\hline Fearing that exercise will damage burn injury & 19 & 14.7 \\
\hline The exercises necessary to be done by the child are not taught & 27 & 16.7 \\
\hline Lack of physical environment appropriate for exercises & 8 & 4.9 \\
\hline Other (the mother is tense etc.) & 3 & 1.9 \\
\hline \multicolumn{3}{|l|}{ Problems regarding feeding/nutrition (n:73) } \\
\hline Not knowing the importance of feeding/nutrition in healing burn injury & 1 & 0.6 \\
\hline Not knowing the food groups useful to heal the burn injury & 1 & 0.6 \\
\hline The child does not want to eat & 48 & 29.6 \\
\hline Not paying sufficient attention to child's nutrition & 8 & 4.9 \\
\hline The child throws up when parents insist on feeding him/her & 14 & 8.6 \\
\hline Other (the child das loss of appetite etc.) & 1 & 0.6 \\
\hline \multicolumn{3}{|l|}{ Problems regarding social communication ( $\mathrm{n}: 204)$} \\
\hline The child s tense and anxious due to increased attention & 83 & 51.2 \\
\hline The child wants to be alone due to changes in body image & 39 & 24.1 \\
\hline The child cannot communicate because his/her friends are anxious about his/her appearance & 16 & 9.9 \\
\hline The child cannot be taken to social environments since his/her burn injuries are not healed & 44 & 27.2 \\
\hline The child avoids talking about bad experiences with his/her friends & 15 & 9.3 \\
\hline Other (the child hides his/her burn injuries etc.) & 7 & 4.3 \\
\hline
\end{tabular}

*Participants provided more than one answer 
in $34.6 \%$ of the cases. Most (93.2\%) of the families said that they did not know the importance of using medication after discharge, and $51.2 \%$ of them expressed that their children were tense and anxious because they showed more interest in their children after discharge. Some (41.4\%) of them said that they could not bathe their children because they were afraid of hurting the burn injury, and $36.4 \%$ of them reported problems getting their children dressed due to increased pain their children felt. Families (29.6\%) also mentioned problems with their children's loss of interest in eating after discharge, and $18.5 \%$ of them reported that they did not know the significance of exercise after discharge and $13.0 \%$ of them stated that they were not able to dress wounds regularly because they did not have healthcare facilities near their homes.

The families' state anxiety mean score after discharge was $47.03 \pm 7.48$ points. The state anxiety mean scores of families who experienced problems

Table 5. State anxiety mean scores and comparing mean scores after discharge.

\begin{tabular}{|c|c|c|c|c|c|}
\hline \multicolumn{2}{|c|}{ State Anxiety Mean Score } & \multirow{2}{*}{$\frac{\mathbf{N}}{162}$} & $X \pm S S$ & \multirow{2}{*}{$\frac{\text { Min. }}{31.00}$} & \multirow{2}{*}{$\begin{array}{l}\text { Max. } \\
62.00\end{array}$} \\
\hline & & & $10047.03 \pm 7$ & & \\
\hline $\begin{array}{l}\text { Parents Experience } \\
\text { Following Discharg }\end{array}$ & ed Proble & & $\begin{array}{c}\text { State Anxiety } \\
\text { Mean Score } \\
\text { X } \pm \text { SS }\end{array}$ & $\mathbf{t}$ & p \\
\hline \multicolumn{6}{|l|}{ Using medication } \\
\hline $\begin{array}{l}\text { Problems } \\
\text { No problems } \\
\text { Dressing wounds }\end{array}$ & $\begin{array}{l}(n: 100) \\
(n: 62)\end{array}$ & & $\begin{array}{l}47.44 \pm 7.69 \\
46.38 \pm 7.16\end{array}$ & 0.869 & 0.386 \\
\hline Problems & $(n: 56)$ & & $48.08 \pm 7.35$ & 1.303 & 0.195 \\
\hline $\begin{array}{l}\text { No problems } \\
\text { Bathing }\end{array}$ & $(n: 106)$ & & $46.48 \pm 7.53$ & & \\
\hline $\begin{array}{l}\text { Problems } \\
\text { No problems }\end{array}$ & $\begin{array}{l}(n: 132) \\
(n: 30)\end{array}$ & & $\begin{array}{l}47.50 \pm 7.57 \\
44.96 \pm 6.85\end{array}$ & -1.687 & 0.185 \\
\hline Getting dressed & & & & & \\
\hline $\begin{array}{l}\text { Problems } \\
\text { No problems }\end{array}$ & $\begin{array}{l}(n: 102) \\
(n: 60)\end{array}$ & & $\begin{array}{l}48.21 \pm 7.50 \\
45.03 \pm 7.07\end{array}$ & -2.661 & $0.009 *$ \\
\hline Exercise & & & & & \\
\hline $\begin{array}{l}\text { Problems } \\
\text { No problems }\end{array}$ & $\begin{array}{l}(n: 88) \\
(n: 74)\end{array}$ & & $\begin{array}{l}46.53 \pm 7.57 \\
47.63 \pm 7.39\end{array}$ & -0.932 & 0.353 \\
\hline Nutrition & & & & & \\
\hline $\begin{array}{l}\text { Problems } \\
\text { No problems }\end{array}$ & $\begin{array}{l}(\mathrm{n}: 66) \\
(\mathrm{n}: 96)\end{array}$ & & $\begin{array}{l}47.95 \pm 6.94 \\
46.40 \pm 7.92\end{array}$ & 1.296 & 0.197 \\
\hline Social communicat & tion & & & & \\
\hline $\begin{array}{l}\text { Problems } \\
\text { No problems }\end{array}$ & $\begin{array}{l}(n: 126) \\
(n: 36)\end{array}$ & & $\begin{array}{l}47.46 \pm 7.57 \\
45.52 \pm 7.57\end{array}$ & -1.375 & 0.171 \\
\hline
\end{tabular}

${ }^{*} p<0.05$ with following daily living activities after discharge were as indicated in parentheses:getting dressed $(48.21 \pm 7.50)$, dressing wounds (48.08 \pm 7.35$)$, nutrition (47.95 \pm 6.94$)$, social communication $(47.46 \pm 7.57)$, using medication (47.44 \pm 7.69$)$, bathing $(47.50 \pm 7.57)$, doing exercises $(46.53 \pm 7.57)$ and nutrition (46.40 \pm 7.92$)$ A statistically significant difference was determined between the state anxiety mean scores of parents who experienced problems with getting dressed after discharge $(48.21 \pm 7.50)$ and those who did not $(45.03 \pm 7.07)$ (t:-2.661 $\mathrm{p}<0.05)$ (Table 5).

\section{DISCUSSION}

In this study, the mean age of the 162 children with burn injuries was found to be $3.40 \pm 3.38$ years which is similar to the mean age of children with burn injuries in previous studies ${ }^{(2,18)}$. The fact that children in this age group are highly involved in playing is believed to increase the incidence of burn injuries. Due to the development of autonomy and a sense of identity and improvements in motor skills in this period, children may develop dangerous behaviors and causing the frequency of home accidents to increase ${ }^{(7)}$.

Of the children with burn injuries, $54.3 \%$ were males, which is similar to the findings in the literature about the gender of burn injury cases ${ }^{(2,10,18)}$. It is believed that boys experience more burn injuries because they are more active than girls by nature.

The study found that $85.2 \%$ of the participating mothers were housewives and $63.0 \%$ had completed primary school. More than half of the participating fathers $(51.2 \%)$ were workers and $60.5 \%$ of them had completed primary school. The income of $74.1 \%$ of the families was equal to their expenses. In their study of family relationships after burn injuries, Moi and Gjengedal ${ }^{(13)}$ determined that $50 \%$ of the children of unemployed families had more frequently experienced burn incidents. The literature, indicates that families' socioeconomic levels directly affect family relationships and child care. Thus, the children of the families with socioeconomic problems may more frequently experience burn incidents.

Most (70.4\%) children experienced thermal burns 
(scalding), and $10.5 \%$ of them contact burns (touching a stove or iron, etc). A study conducted in Turkey in 2013 determined that $85.6 \%$ of the children were injured by scalding, $9.6 \%$ by flames/fire, $2.6 \%$ by electricity and $1.8 \%$ by contact burns ${ }^{(18)}$. These results resemble those in literature.

This study determined that after discharge, 81.5\% of the familieshad problems with bathing their children, $77.8 \%$ with social communication, $63.0 \%$ with dressing, $61.7 \%$ with medication, $54.3 \%$ with exercises, $40.7 \%$ with nutrition and $34.6 \%$ with dressing wounds. In a qualitative study conducted by Öster, Hensing, Löjdström, Sjöberg et al. ${ }^{(16)}$ ( $\mathrm{n:10)}$ ), the investigators found that children and families had problems with getting dressed, dressing wounds, body image, going back to their old lives and returning to school. Providing training to families before they leave the hospital about the problems that will be experienced after discharge and their solutions is crucial.

Examination of the causes of problems after discharge pointed to families' lack of knowledge (92.2\%) about using medication ${ }^{(7)}$. This finding points to the fact that families are not provided with sufficient information before discharge about the effects of medication on burns and the necessity to use medication until healing is complete. It is thought that training on the use of medication should be provided at discharge with the help of printed materials or visual aids.

It was found that burn wounds of children of $13 \%$ of the families could not be dressed regularly after discharge because lack of a healthcare facility nearby. No information was found in literature about this problems. However, like the literature ${ }^{(4,5)}$, this study found that there were problems with dressing wounds after discharge. It may be that the families were not able to get their children's wounds dressed regularly due to lack of information and poor socioeconomic conditions.

A study of the expectations of patients with burn injuries from their nurses, reported that $33.7 \%$ of the patients expected nurses' support with getting dressed, and $22.8 \%$ of them anticipated their support with meeting basic needs. Most (96\%) patients, reported that they wanted to learn about skin care after discharge ${ }^{(9)}$. Şahin, Dal and Vural ${ }^{(8)}$ also reported that families needed more precise information about selecting clothes, dressing and bathing. Some families $(41.4 \%)$ participated in this study, stated that they did not bathe their children for fear of harming their burn injuries. The parents believed that clothing could hurt the burn wound may also be related to insufficient information. It is apparent that families should be informed that they should dress their children in soft, cotton, loose and light colored clothing.

Examination of the causes of problems with exercising after discharge found that $18.5 \%$ of the parents did not know the significance of exercise for the extremities. A study conducted about life quality in children after burn incidents ( $\mathrm{n}: 138)$ reported that $11 \%$ of the burn victims experienced problems with regular daily activities ${ }^{(7)}$. Doing exercises is important for children's physical, social and mental functions and it also prevents the formation of contracture due to complications. Therefore, teaching the exercises to children and their familiars via team work will minimize problems experienced after discharge.

Some (29.8\%) families complained that their children did not want to eat after discharge. This may be related to loss of appetite. Studies have shown that children may experience short-term appetite loss after discharge ${ }^{(10,14)}$. It is believed that families should be patient about feeding their children and ensure that they are provided with sufficient vitamins, minerals and proteins.

Regarding social communication after discharge, $51.2 \%$ of the families reported that they paid more attention to their children because of the burn injury, and their children became tenser and more anxious as a result. Previous studies have also reported that school age children present long-term behavioral problems depending on the degree of the burn and as a consequence, their anxiety levels increase ${ }^{(3)}$.

Studies have shown that families need support in burn care from relatives or other family members (1,5). Hence, it is expected that psychological support will decrease families' burden of care However, this 
study found that families who received psychological or psychiatric care, experienced greater number of problems after discharge although there was no statistically significant difference. This finding may be related to collecting data only iconcerning the first month after discharge. The process of support may not have been completed only in this one-month period. The families may have experienced greater number of problems due to short-term support.

Children's burn injuries negatively affect both lives of both parents' and children. Parents are expected to experience difficulty coping with their children's stress because they strive to help their children and apply the procedures they have learned about burn care at home. Therefore their anxiety increases ${ }^{(3,7,10)}$. This study has also found that families' mean state anxiety score was increased $(47.03 \pm 7.48)$. The state anxiety scores of parents who experienced difficulties in the field of getting their children dressed were higher than those who did not experience problems in this area (t:-2.661 $p<0.05)$. This finding may be due to the fact that getting children dressed is both a time-consuming and stressful task after a burn incident. Although there was no statistically significant difference between the state anxiety mean scores of the families who did and did not experience problems in other areas. it was determined that generally the state anxiety mean scores of families who experienced problems were higher. Hence, having many problems with home care caused their state anxiety levels to increase. If the state anxiety levels of the families had been measured immediately after the incident, they may have been even higher, but since these levels were measured approximately one month after their discharge from the hospital, they may have decreased. Their state anxiety had started to transform into trait anxiety due to problems with burns at home. Initiatives to minimize families' anxiety should start before discharge and continue at home.

\section{Limitations and Future Directions}

This study is not without limitations. However, qualitative studies on this issue should be conducted. Also support groups should be established to share the experiences of families on burn care and process. Home visits should be made at regular intervals in order to help families with problems they will encounter after discharge.

\section{CONCLUSION}

This study found that parents experienced various problems after discharge: problems with using medication, dressing wounds, bathing, getting dressed, exercise, nutrition and social communication. It takes a long time for individuals with burn injuries to adapt fully to social life. The role and function of home care nurses are crucial in this process. It is believed that providing one to one interactive training for parents using visual training materials about possible problems after discharge, ensuring regular home visits to minimize their problems and providing regular phone consultations will help to prevent development of hardships. Forming support groups for parents to share their experiences with burn care will provide support for children and parents and facilitate their adaptation to the significant changes caused by burn injuries.

\section{Acknowledgements}

The authors would like to thank all the patients and their families who participated in this study. We would also like to express our sincere gratitude for support of surgeons, nurses and health personnel in Ege University Department of Pediatrıc Surgery.

Ethics Committee Approval: Approval was obtained from the Non-Interventional Clinical Research Ethics Committee of Dokuz Eylül University (2015 / 02-29) (22.11.2015).

Conflict of Interest: No conflict of interest was declared by the authors.

Funding: This research received no specific grant from funding agency in the public, commerical, or not-fot-profit sectors.

Informed Consent: Verbal and written informed consent was obtained from families before the study was conducted. 


\section{REFERENCES}

1. Reis E, Yastı AC, Kerimoğlu RS. The effects of habitual negligence among families with respect to pediatric burns. TJTES. 2009;15(6):607-10. Available form: http://tjtes.org/eng/jvi. aspx?un=UTD-94758

2. Aliustaoğlu S, İnce H, İnce N, Yazıcı Y, Berber B, Güloğlu R. Evaluation of "life-threatening" definition and negligence in children treated in the emergency surgery service burn unit (from the viewpoint of forensic medicine). TJTES. 2010;16(2):170-3. Available form: http://www.tjtes.org/tr/ jvi.aspx?pdir=travma\&plng=tur\&un=UTD-20053

3. Bakker A, Van Loey N, Van der Heijden P, Van Son M. Acute stress reactions in couple after a burn event to their young child. J Pediatr Psychol. 2012;37(10):1127-35. https://doi.org/10.1093/jpepsy/jss083

4. Faydalı S, Bayraktar N. Determination of post-discharge knowledge levels of burn patients and their relatives. HEMAR-G. 2011;1:47-60. Available form: http://hemarge. org.tr/ckfinder/userfiles/files/2011/2011-vol13-sayi1-131. pdf

5. Gaugliz G. Long-term physiopathology of burns and results; scar formation, HTS, keloid and scar treatment, rehabilitation, exercises. In Jeechke MG, Kamolz LP, Shahrokni S (eds). Burn Care and Treatment. $1^{\text {st }}$ ed. İstanbul, Nobel Tip Kitapevleri, 2015. p.157-65.

https://doi.org/10.1007/978-3-7091-1133-8_10

6. Rosenberg M, Celis MM, Meyer W, Tropez-Arceneaux L, McEntire SJ, Fuchs $\mathrm{H}$, et al. Effects of a hospital based wellness and exercise program on quality of life of children with severe burns. Burns. 2013;39(4):599-609.

https://doi.org/10.1016/j.burns.2012.08.019

7. Van Baar ME, Polinder S, Essink-Bot, ML, et al. Quality of life after burns in childhood (5-15 years): Children experience substantial problems. Burns. 2011;37(6):930-8. https://doi.org/10.1016/j.burns.2011.05.004

8. Şahin YS, Dal Ü, Vural G. Burn patient expectations from nurses. TAF Preventive Medicine Bulletin. 2014;13(1):37-46. Available form: http://eds.a.ebscohost.com/eds/pdfviewer/ pdfviewer?vid=0\&sid=8d97ab3d-1500-497a-bb628364cb79e963\%40sessionmgr4008

9. Tuna Z, Çetin C. Quality of life and affecting factors ofquality of life of burn patients. HUHEMFAD-JOHUFON. 2010;17(2):112. Available form: https://dergipark.org.tr/tr/download/ article-file/88513
10. Thompson KL, Leu MG, Drummond KL, Popalisky J, Spencer SM, Lenssen PM. Nutrition Interventions to optimize pediatric wound healing: An evidence-based clinical pathway. NCP. 2014;29(4):473-82. https://doi.org/10.1177/0884533614533350

11. McGarry S, Elliott C, McDonald A, Valentine J, Wood F, Gridler S. Pediatric burns: from the voice of the child. Burns. 2014;40(4):606-15. https://doi.org/10.1016/j.burns.2013.08.031

12. McGarry S, Elliott C, McDonald A, Valentine J, Wood F, Gridler S. "This is not just a little accident": A qualitative understanding of paediatric burns from the perspective of parents. Disabil Rehabil. 2014;37(1):41-50. https://doi.org/10.3109/09638288.2014.892640

13. Moi AL, Gjengedal E. The lived experience of relationships after majör burn injury. J Clin Nurs. 2014;23(15-16):2323-31. https://doi.org/10.1111/jocn.12514

14. Rousseau AF, Losser MR, Ichai C, Berger MM. ESPEN endorsed recommendations: nutritional therapy in major burns. Clin Nutr. 2013;32(4):497-502. https://doi.org/10.1016/j.clnu.2013.02.012

15. Bakker A, Maertens KJP, Van Son MJM, Van Loey NEE. Psycholoical consequences of pediatric burns from a child and family perspective: A rewiev of the empirical literature. Clin Psychol Rev. 2013;33(3):361-71. https://doi.org/10.1016/j.cpr.2012.12.006

16. Öster C, Hensing I, Löjdström T, Sjöberg F, Willebrand M. Parents perceptions of adaptation and family life after burn injuries in children. J Pediatr Nurs. 2014;29(6):606-13. https://doi.org/10.1016/j.pedn.2014.06.010

17. Yılmaz F, Arıkan D, Baklacı Ö, Bilmez A, Bülbül D. Drug administration in pediatric nursing. Journal of Anatolia Nursing and Health Sciences. 2013;16(2):82-8. Available from: https://dergipark.org.tr/en/download/article-file/29302

18. Arslan H, Kul B, Derebaşınlıoğlu H, Çetinkale O. Epidemiology of pediatric burn injuries in Istanbul, Turkey. TJTES. 2013;19(2):123-6. https://doi.org/10.5505/tjtes.2013.44442

19. Öner N., Le Compte A. Discontinuous state/trait anxiety inventory handbook, $1^{\text {st }}$ ed. Istanbul: Boğaziçi University Publications; 1983. p. 1-26.

20. Aksakoğlu G. Research and analysis in health. $2^{\text {nd }}$ ed., İzmir, D.E.Ü. Rectorate Printing House, 2006.

21. Bahar Z. Statistical methods in data analysis. In: Erefe I, ed. Research Principles and Processes in Nursing. $4^{\text {th }}$ ed. Ankara, Odak Ofset Printing; 2012. p. 189-246. 